\title{
The Social Constructionist Challenge to Primacy Identity and the Emancipation of Oppressed Groups: Human Primacy Identity Politics and the Human/'Animal' Dualism
}

\author{
by Kay Peggs \\ University of Portsmouth \\ Sociological Research Online, Volume 14, Issue 1, \\ < http://unw. socresonline.org.uk/14/1/3.html> \\ doi:10.5153/sro. 1833
}

Received: 3 Sep 2008 Accepted: 8 Dec 2008 Published: 31 Jan 2009

\begin{abstract}
In a recent issue of this journal Mike Homfray asserted that social constructionism challenges emancipatory politics based in essential conceptualisations of identity. Thus for Homfray the concept of identity as associated with the pre-deconstructed subject is central for the emancipatory goal of oppressed groups like the lesbian and gay movements. In this paper I offer a distinction between radical identity politics that seeks to liberate oppressed groups, and what I have called primacy identity politics in which primacy identity is used to preserve the subjugation of those who are oppressed. In so doing I put forward a challenge to Homfray's somewhat wholesale rejection of the capacity for a critique of identity to work for emancipatory politics by focussing on primacy identity politics rather than on radical identity politics. In making an argument for the deconstruction of identities for emancipatory purposes I refer to my work on the human oppression of nonhuman animals. In this work I turn my attention away from those who are oppressed to the oppressors because this transfer of attention shows how useful the deconstruction of identity could be for the emancipation of oppressed groups. My examination of discourses used by the pro nonhuman animal experimentation lobby group Pro-Test shows how primacy identity politics can effectively be challenged by a social constructionist critique of essential identities and thus, contra Homfrey, I conclude that the deconstruction of identities can strengthen emancipatory causes.
\end{abstract}

\section{Keywords: Human, Identity Politics, Nonhuman, Oppressed, Performative, Primacy, Radical, Social Construction}

\section{Introduction}

1.1 Recently in Sociological Research Online Mike Homfray (2008) put forward a critique of social constructionist sociology for a standpoint position in social research and for the goal of emancipation as associated with identity politics. In this paper I offer commentary on his concerns about the problems of social constructionism for emancipatory identity politics by putting forward an argument about the potential emancipatory consequences of social constructionist opposition to what I have called primacy identity politics (Peggs, in press ). Though Homfray does not argue for the abandonment of social constructionism (2008: para 5.14), he asserts that social constructionism challenges the emancipatory politics of lesbians and gay men, in a society that discriminates on the grounds of sexuality. The relationship between political struggle and the social constructionist critique of identity, and the challenge this is seen to pose to identity politics, is also a major concern in contemporary feminist theory (e.g. see Lloyd 2005, 2007; Holmes 2007). For example, Mary Holmes notes that, for second-wave feminists, '[p]olitical unity between women was possible if they recognised this common identity and shared oppression' (2007: 118) but, as Moya Lloyd comments, 'différance feminism' deconstructed the 'unified feminist subject', and in so doing left the question '[i]f women do not exist, who is feminism supposed to liberate?' (2007: 6). This deconstructionist shift has been followed through in lesbian and gay politics (Lloyd 2007: 7), and this leads Homfray to assert that for lesbians and gay men ' $[a]$ standpoint needs to be based on more than simply a construction which has almost no base in the real world, as does the achievement of genuine emancipation' (2008: para 5.6). Thus the concept of 'identity' as associated with the pre-deconstructed essential subject is viewed to be central for the emancipatory goal of oppressed groups because '[i]dentity politics operates with the assumption that one's identity - as a woman, or gay man, or African American - furnishes the grounds for a collective politics' (Lloyd 2007: 2). Consequently, the social constructionist critique of identity is seen as a challenge to the emancipatory goal of identity politics. My focus is not on Homfray's argument about the 
specific case of lesbian and gay identity politics but rather is on his more general criticisms of the social constructionist critique of identity for the emancipatory goal of identity politics. Though I can see Homfray's argument I want to challenge his somewhat wholesale rejection of the capacity for a social constructionist critique of identity to work for emancipatory politics by focussing on primacy identity politics rather than on radical identity politics. Accordingly, in this paper I offer a distinction between radical identity politics that seeks to liberate oppressed groups and primacy identity politics, in which primacy identity is used to preserve the subjugation of those who are oppressed. So what I aim to do is turn my attention away from the identities of those who are oppressed to the identities of oppressors since, I argue, this transfer of attention shows how useful the deconstruction of identity could be for the emancipation of oppressed groups. Indeed I argue that primacy identity politics can be effectively challenged by a social constructionist critique of essential identities and thus, contra Homfrey, the deconstruction of identities can strengthen emancipatory causes.

1.2 In making an argument for the deconstruction of identities for emancipatory purposes I refer to my work on human oppression of nonhuman animals. In this work I focus my attention away from the identity of 'the other' (the nonhuman animal) to the construction of the identity of the 'in group' (the human); thus I centre on those who see their 'natural' place as being superior to 'the other'. In so doing I apply the critique of identity to the dualism human/'animal', though my critique does not have to stop there, and in the case of Homfray's work could be equally applied to hierarchical categorisations associated with sexuality. In the first section of this paper I briefly summarize what I read to be Homfray's argument. Since identity is so central to the issues discussed, I devote the second section to the conceptualisation of (human) identity and follow this with a section on (primacy) identity politics. To provide illustration of primacy identity politics, in the third section I turn my attention to the lobby group Pro-Test, a group that promotes the use of nonhuman animals in experiments. This leads me to conclude that the continued assumption of an essential (superior) identity buttresses the subordination of oppressed groups whereas the deconstruction of identity and the dissolution of the power connected with primacy identity could lead to the emancipation of oppressed groups. This is because a critique of identity can strengthen emancipatory political goals by deconstructing primacy identity claims.

\section{Standpoint, Objectivity, and Social Construction: Mike Homfray's thesis}

2.1 Mike Homfray argues that there are limitations to social constructionism for emancipatory causes. He is troubled by the implications of social constructionism for lesbians and gay men since " "reality" itself is viewed as little more than a performance' (2008: para. 4.3). Homfray depicts social constructionism as challenging the 'biological constraints of essentialist ideas' (2008: para 4.4). Though social constructionist perspectives are multifarious, broadly a social constructionist critique of identity focuses on conceptualisations of whom we are as based not in a biological essential that is given but rather in the socially produced that is performed (e.g. see Butler 1999). Homfray explains that performative sexual identity is not the experience of the lesbians and gay men he interviewed as they were much more likely to display a 'mild essentialism' (2008: para 4.10) because, he contends with reference to Vera Whisman (1996), lesbians and gay men 'do not primarily view their sexuality as chosen or socially constructed' (in Homfray 2008: para 4.9). This observation leads Homfray to favour Nicholas Bamforth's 'moderate constructionism', which 'accepts that there is an "essence" which, though interpreted in social context, is integral to the person' (Bamforth quoted in Homfray 2008: para 4.6).

2.2 Homfray is especially troubled by queer theory which, he argues, is the 'nadir of this extreme constructionist approach' (para 5.2) and in citing Judith Butler's work on hate speech he asks, '[d]oes a reduction of hate speech (often accompanied in reality by hateful action) to "performativity" assist the gay man or lesbian being verbally or physically harassed in the real world?' (2008: para 5.5). He understandably declares that it does not. As a result, he suggests that 'caution needs to be applied...to the entire "constructionist" project in its more profound or thoroughgoing forms' (2008: para 5.6). The problem as Homfray sees it is that social constructionism has led to a 'drift of [sociological] research into lesbian and gay concerns away from sociological priorities, and, ultimately, from social or political change' (2008: para 5.6). For Homfray, "[p]olitical identity has to be "essentialist" from the perspective of achieving social change, because social change is achieved and experienced collectively, via movements' (2008: para 5.7). Consequently, from Homfray's point of view, for emancipatory political change to take place, an essential identity is vital. This viewpoint resonates with feminist arguments that propose that the lack of a conception of a stable identity established in what women share means that the political goal of women's liberation is unworkable (for overviews see e.g. Lloyd 2005, Holmes 2007). Thus Homfray contends ' $[\mathrm{t}]$ he basis of my research involves the actual experiences of gay men and lesbians, working for social change, within their communities, and if we cannot even recognise any idea of "identity", then the thought of basing change on a community of interest is simply not viable' (2008: para 5.7). However, in challenge to Homfray's viewpoint, in what remains of this paper I explore Moya Lloyd's contention that a critique of essential identity claims achieved by means of a focus on performative identities can strengthen emancipatory political goals since 
such a focus 'facilitates an understanding of how particular identity claims have been (and may continue to be) made' (2005: 30). So, coming back to hate speech against lesbians and gay men and the hateful action that often follows, my argument is that the deconstruction of the primacy identity of hate speakers could assist in the emancipatory cause of lesbians and gay men. This is because a critique of essential notions of identity can strengthen emancipatory political goals by deconstructing primacy identity claims. In the following section I explore claims of essential primacy identity, claims that are evident in the human/'animal' dualism, the dualism on which I base the rest of my argument.

\section{Belonging, Difference and Exclusion: the Making of (Human) Identities}

\subsection{Sociological conceptualisations of identity have moved away from the idea of fixed essential identities} to a focus on deconstructed identification (Hall, 1996) ${ }^{[1]}$. The part played by human agency in identification is seen as crucial. For example, Anthony Giddens' notion of the self as a reflexive project points to the ways in which identity is constituted by a reflexive ordering of self-narratives (Adkins 2001: 35). Thus, Giddens argues, the self is revised and negotiated though a 'narrative of self-identity', (1991: 185) as 'selfidentity has to be created and more or less continually re-ordered against the backdrop of shifting experiences of day-to-day life and the fragmenting tendencies of modern institutions' (1991: 186). So we might adjust, hide or accentuate aspects of our identities, for example features of our behaviour or our appearance, in order to fit in with what we see as the specific requirements associated with particular public and private spaces (Giddens 1991). Of course, some aspects of our identities can feel fixed, and what Richard Jenkins (2004) calls 'primary identities' (that is identities like gender that are established in earlier life $^{[2]}$ ), usually seem 'more robust and resilient to change in later life than other identities' (Jenkins 2004: 19). What is more, even for aspects that feel less fixed or even unfixed, seeing the self as flexible and adaptable should not detract from how we experience our self-identity as a more or less unitary identity. So, though our identities might be flexible and different aspects perhaps seem contradictory, we recognise our selfhood as 'thoroughly interconnected and interdependent...'(Jenkins 2004: 45).

3.2 Given that for social constructionists identity is an active venture, identity can be seen as a performance where an identity is an accomplishment, acted in the theatre of everyday life (Goffman 1969) and where, as Jack Barbalet contends, ' $[\mathrm{t}]$ he ultimate outcome, increasingly taken as a real option, is that the self, rather than simply focusing on a core of being which persons are subjectively aware of, becomes a conscious project of our own activity' (2001: 119). So although individuals may be mindful of the selves they work on and transmit, they experience themselves as having an essential inner core. It is therefore not surprising that the lesbians and gay men Homfray interviewed displayed a 'mild essentialism' (2008: para 4.10) and indeed this resonated with my research with Richard Lampard on couple relationships as we found that 'our interviewees experience their identities as performances, with a central, 'authentic', inner identity performing the drama.' (Lampard and Peggs, 2007: 204 original emphasis). Nevertheless, just because people may experience their identities as performances with essential inner cores this does not necessarily work against theoretical deconstructions of identity that focus on the performative.

3.3 The notion of performative identity challenges the very idea of an essential inner core of being, and so there is no essential inner self with which performances associate. Accordingly performativity is different from performance since performance presumes the existence of an essential subject whereas performativity disputes the existence of such a subject (Osborne and Segal, 1994). For example, Butler (1999) counters the idea that there is something essential to gender identity. For Butler, the 'essential' male or female identity is an illusion, the effect of ongoing performances of gender. So, Butler contends, '[g]ender reality is performative which means, quite simply, that it is real only to the extent that it is performed' (1999: 278). Thus the reality of an identity is not based in its essential core; rather the reality of an identity is based in its performed existence, and a male or female identity is not the cause of gender performance but rather the reverse. Accordingly, for Butler, gender is reiterated through stylised and repeatable acts with the implication that 'gender is not an expression of what one is; it is what one does' (Lloyd, 2005: 25). Consequently Lloyd (2005) maintains that this enables an examination of the processes by which identities are made and asserted. This conceptualisation of performative identities is central to my line of reasoning because, as I have argued elsewhere (Peggs in press), in its challenge to essentialist ideas of identity, performative notions of identity enable an exploration of primacy identity claims. This affords the capacity to focus on the social construction of, rather than on a natural disposition to, specific identities and, in terms of my research, to centre on human identification as the opposite of 'animal', as a phenomenon that is the product of human power rather than as something that is essential.

3.4 Sociological thought on identity focuses on notions of belonging, difference and exclusion and so the self has a 'dydactic structure (self versus other...)' (Lloyd 2005: 20). Indeed Stuart Hall contends that identities are 'more the product of the marking of difference and exclusion, than they are the sign of identical, naturally-constituted unity' (1996: 4). Turning to the human nonhuman animal distinction, essentialist assumptions about the differences between humans and nonhuman animals and the conflating 
of nonhuman animals into a large assemblage as distinct 'other' has, of course, a very long history. For example, Aristotle saw the difference between humans and nature (of which nonhuman animals were seen as a part) as a hierarchical continuum with humans at the apex (Anderson 1998: 30) and in the seventeenth century the 'conceptual ground was...cleared to differentiate 'human' nature from 'animal' nature' (Anderson 1998: 30) via Rene Descartes (1968) notion that 'the mind is distinct from and superior to matter' (Sutcliffe, 1968: 19). For Descartes 'reason or good sense makes us men (sic) and distinguishes us from the animals' (Sutcliffe 1968: 27). Cartesian scientists accorded humans access to our conscious minds and although nonhuman animals were seen as capable of the bodily sense of pain they were declared incapable of thinking and hence incapable of feeling pain (Anderson 1998: 30, Rowlands, 2002: 3). Kay Anderson argues that "[h]enceforth, the conceptual boundaries between "animal" and "human" were increasingly chauvinistically drawn within the larger Cartesian framework of Western dualistic thought' (Anderson 1998:30). Of course, Descartes' ideas have been subject to major criticisms (for discussion see e.g. Midgley, 2002 [1979], Rowlands 2002) but still humans view humans as essentially distinct from, and usually superior to, nonhuman animals (for discussion see e.g. Singer 2002) and thus the vast formation classified 'animal' is conceptualised as the essential, generally inferior, contrast of human.

3.5 Because nonhuman animals are so diverse, Jacques Derrida challenges the singular 'animal' as an allinclusive marker for all those classified as nonhuman animals (Ito 2008: 123). In this regard he argues that ' $[\mathrm{t}$ ]here is no animal in the general singular, separated from man (sic) by a single indivisible limit' (Derrida, 2004: 125). While, as Mimeo Ito (2008) contends, Derrida upholds the distinction between human and nonhuman animals, Derrida also maintains that '[b]eyond the edge of the so-called human, beyond it but by no means of a single opposing side, rather than "the Animal" or "Animal Life" there is already a

heterogeneous multiplicity of the living' (Derrida 2004: 125). So although Derrida argues that his thesis does not 'mean ignoring or effacing everything that separates humankind from the other animals' (2004: 125) his ideas can help us question our notions of essential hierarchical differences between human and nonhuman animals. Derrida's work facilitates the uncovering of the power relations inherent in the social construction of human identity, which assumptions based in the 'essential' obscure (e.g. see Peggs, in press). What Derrida's work reveals, as Ernesto Laclau contends, is that the 'constitution of identity is an act of power' (1990: 33) since for Derrida, the foundation of identity is exclusion established in hierarchically defined binary oppositions (Laclau, 1990: 33) like human and 'animal'. In this configuration the 'marked' term 'animal' is allocated to the subordinate limit of the 'violent hierarchy between the two resultant poles' (Laclau, 1990: 33) and the marking of the term 'animal' at the base pole is established in essentialist discourses about 'natural' divisions between 'us' and 'them,' positing a distinctive essential human identity, and a distinct essential 'animal' other (see Peggs, in press). Thus, as Anderson argues, the 'imaginative act' that incorporates nonhuman animals into the category 'nature' enabled nonhuman animals to be set as a rival, along with nature, as 'both against and beneath the human, who was henceforth justified as treating nature as object, as background to - and instrument of - human purposes' (Anderson 1998: 30 original emphasis). This brings me to identity politics, and in particular to human primacy identity politics, where my focus is on the construction of the identity of the 'in group' and the politics of those who see their 'natural' place as being superior to 'the other'.

\section{Identity politics}

4.1 Rather than being experienced as chosen, Homfray argues that lesbians and gay men often experience their sexuality as essential (2008: para 4.10). For Homfray this essentiality is necessary for social and political change because the very real discriminations that are experienced by lesbians and gay men are precisely that, very real. Let us be clear, I have no doubt at all that lesbians and gay men experience very real discrimination in what Lloyd (2007) calls 'heteronormative' social structures, but my questions is; does a critique of essential identities necessarily contradict an emancipatory politics grounded in the liberation of oppressed groups? There are a number of ways of addressing this question but what I want to focus on here is the dismantling of the assumed essential primacy identities of powerful discriminatory groups.

4.2 Identity politics is conceptualised as an emancipatory politics that focuses on the liberation of oppressed groups (Lloyd 2007). Thus in identity politics the goal is usually 'the call to 'respect' traditionally disadvantaged social groups' (Fuller, 2006: 111-2), and movements like the lesbian and gay movement and the feminist movement were conceived in this way (Lloyd 2007: 7). Regarding the women's movement Holmes comments that '[t]he emphasis on embodied identity/experience as the 'proper' basis for feminist knowledge and action was at times a radicalizing position' (2007: 121). Thus, as Lloyd notes, 'the identity 'woman' becomes political (becomes feminist) when an antagonism emerges with men or patriarchy' (2005: 20). Coming back to Homfray's article, he echoes this view because he maintains that 'the experience of discrimination on the grounds of sexual orientation is likely to remain, and this will, in turn, retain the need for gay and lesbian people to maintain organisational networks and collaborations' (2008: para 2.25). Though I am not arguing against this, what I challenge is the suggested necessity of 'a predominantly realist theoretical framework' (Homfray 2008: para 5.14) for emancipatory purposes. What I want to argue is 
that a deconstructionist approach to identity can also be employed for emancipatory purposes, and in what follows I focus on how an emancipatory position can be taken when deconstructing the primacy identities of those who have embraced what they see as their superior essence. Accordingly, in this paper I separate identity politics into two strands by offering a distinction between radical identity politics that seeks to liberate oppressed groups and primacy identity politics in which primacy identity is used to maintain the subjugation of those who are oppressed. In order to explicate this distinction I concentrate on notions of biological difference that centre on the human/'animal' dualism.

4.3 It would be absurd to suggest that differences and similarities do not exist among all animals, e.g. I am a female mammal and the mammal who lives next door to me is also a female. Thinking back to Butler's work, in terms of sex differences she does not suggest that organic differences do not exist, but she asks, ' ...under what discursive and institutional conditions, do certain biological differences... become the salient characteristics of sex?' (Osborne and Segal, 1994: 36). Coming back to my neighbour, she is categorized as being the same sex as me, however, she is considered to be less like me than the male mammal who lives with me; he is a human and she is a cat. Thus organic similarities and differences become more or less important depending on, to quote Butler, the 'discursive and institutional conditions' within which they are applied. This is of course important for identity politics and, as we have seen, Homfray (2008) argues that the deconstruction of identity negates the real-life lived experience of oppressed lesbian and gay men. What Homfray's argument overlooks is the emancipatory effects that the deconstruction of essential primacy identity could have for oppressed groups.

4.4 As I have argued here and elsewhere (Peggs, in press), there are important differences between radical identity politics and primacy identity politics. In radical identity politics the goal is usually 'to overcome the forms of oppression and marginalization that group members experience' (Lloyd 2007: 2), whereas the goal in primacy identity politics is the preservation or extension of existing power relations through the continued subjugation of disadvantaged groups (Peggs, in press). However, the similarity between radical identity politics and primacy identity politics is that there is an assumed essential identity that is the group's foundation for collective political action. But, coming back to the dissimilarities, in radical identity politics the lack of a conception of an essential identity means that for many activists emancipatory politics is unfeasible (Lloyd, 2005:13) (and this is Homfray's point), whereas in the case of primacy identity politics there are considerable emancipatory possibilities associated with viewing identities as destabilised (Peggs, in press). In order to explicate my argument in what remains of this paper I focus on what I argue are the primacy identity politics of Pro-Test, a UK-based lobby group that supports and promotes experiments ${ }^{[3]}$ on nonhuman animals.

\section{Human Primacy Identity Politics}

5.1 The lobby group Pro-Test (2006a) explains its inception as a response to 'the way that those opposed to vivisection (testing on animals for the purpose of scientific progress) were dominating the public debate on animal research'. Pro-Test's website material describes their major aim as follows;

'Pro-Test aims to counter the irrational arguments of anti-vivisectionists by raising public awareness of the benefits of animal research and creating an environment where scientists can speak out about their work and be proud of the contributions they make' (Pro-Test $2006 a)^{[4]}$.

5.2 The focus here is on the function of nonhuman animals for providing (most usually human) benefits, the commendation of humans who carry out such experiments and the facilitation of a setting in which the functional benefits to (usually) humans and the work being carried out (usually) on behalf of humans is recognised. The notion of functional achievements is pitted against what Pro-Test terms the 'irrational' arguments of those opposed to such experiments, arguments that cover e.g. functional detriments (nonhuman animals experiments as ineffective) and ethical concerns (nonhuman animal experiments as immoral) (e.g. see Pro-Test 2006b). The website explains that Pro-Test is 'funded entirely by voluntary donations from private individuals and a generous grant from the Research Defence Society' (Pro-Test 2006a). The members, the followers, the funders and the scientists defended by the group are of course human, as are the beings Pro-Test refers to as opposed to such experiments. Pro-Test does not mention the opposition that is without doubt felt by other beings; for example the nearly three million nonhuman animals experimented upon in 2006 in the UK alone (National Statistics 2007: pp 18-19). Indeed, Pro-Test (2007) declares that it 'welcome[s] statistics on animal research in 2006' since the political objective of the group is the preservation of experimentation on nonhuman animals for 'scientific progress'.

5.3 Pro-Test does not call for recognition of and an end to the subordination of nonhuman animals, rather Pro-Test pleas for the preservation of the domination of nonhuman animals for human good (Peggs, in press). Of course, Pro-Test does not refer to the use of nonhuman animals in experiments as human 
domination at all; rather Pro-Test associates nonhuman animal experiments with scientific progress. But because Pro-Test does not present nonhuman animal experimentation as human domination this does not detract from the human domination that is surely evident; the experiments are for scientific progress and for sure, it is unlikely that a Pro-Test member, funder or scientist would want to take the place of a nonhuman animal destined for or used in such experiments. However, in defending such experiments, Pro-Test contends that they are not undertaken solely for human good; Pro-Test avers that such experiments are also beneficial to nonhuman animals. Thus Pro-Test argues,

'But animal research hasn't benefited humans alone. Animals also have improved healthcare and a longer lifespan. Farm animals, household pets, wild species and endangered species are all benefiting from the research conducted through animals. There are vaccines for rabies, distemper, tetanus, parvo virus and numerous other illnesses in cats, dogs and countless other domesticated animals... It's obvious that animal research benefits all living species and that we are all able to live longer, healthier, happier lives because of it' (Pro-Test. 2006d).

5.4 Of course, we are not 'all able to live longer, healthier, happier lives' because of nonhuman animal experiments, for example over 100 million nonhuman animals worldwide are used in experiments every year (Rowlands 2002: 124) and their individual lives are not usually longer, healthier or happier as a result of being experimented upon. However, for Pro-Test the benefits are indisputably acceptable because the experimented upon nonhuman animals ('them') are providing benefits for 'all living species' ('them' and 'us'), though it would be indisputably unacceptable if the benefits for all living species ('them' and 'us') resulted from experiments on humans ('us'). I am not for one moment advocating experiments on humans, rather I am trying to elucidate the inferred hierarchical, seemingly essential, differences between human and nonhuman animals that inform the 'in' identity of 'human' and the 'otherness' of all nonhuman animals, which leads to an assumption of acceptable experiments on nonhuman animals. So in my line of reasoning what Pro-Test is doing is promoting nonhuman animal experimentation via discourses that reiterate human primacy assumptions which in turn restate the acceptability of such experiments (Peggs, in press). Let us explore this further by looking in more detail at further sections from the Pro-Test website.

5.5 Firstly I focus on Pro-Test's rationale for drug testing on nonhuman animals. The website material states that,

\footnotetext{
'...because we simply cannot know what the effects of a drug will be in a full animal by testing on cells in a test tube (because neither the cells nor test tube possess a circulatory system, heart, liver, etc, so there is no way of knowing how the drug will be absorbed and affect a living organism), there will always come a point where we must test on a living creature. The choice is then between animals or human beings. In our view, this is an easy choice to make' (Pro-Test 2006b)
}

5.6 Of course, no amount of testing will ever offer facts about what the 'full effects of a drug will be' on a being, because different beings (within and among species) react in different ways. However, taking ProTest's statement as read, the choice as they see it has three phases. First of all, Pro-Test asserts that there is no choice but to test drugs on a living creature. The real choice for Pro-Test comes after this initial phase of no choice, in the act of human choice about which creatures will bear the burden of drug tests. This choice for Pro-Test is 'easy'; nonhuman animals must bear the burden of the test, and in this nonhuman animals have no choice at all. So, to sum up, after the initial phase of no choice for humans (the usually for-human-benefit drug must be tested on a living creature) there comes a second phase of options for humans (which being shall be used in the test?), followed by a third phase of a choice being made (the drug test cannot be carried out on humans so it must be carried out on other beings) with the consequence of no choice for nonhuman animals (the drug will be tested on them). Pro-Test represents the second and third phases as 'easy'; how do they justify this? It seems clear that for Pro-Test the needs of nonhuman animals are less important than those of humans, and human needs permit nonhuman animals to be used as expendable assets when the choice is seen to be between 'them' and 'us'. Nonhuman animals used in experiments are thus ultimately classified as resources (Rowlands, 2002: 196), as a means to a human end rather than as beings who have a value in themselves.

5.7 This brings me to a further section of the website material upon which I want to focus. Although Pro-Test advocates nonhuman animal experiments, the group also stresses that its members and its supporters care about nonhuman animals and their well-being. However, in so doing, Pro-Test reinforces its views about the pre-eminence of human need and the relative dispensability of nonhuman animals in their assertion that 'Animal welfare must be taken into consideration, but ultimately, human beings must come first' (Pro-Test 2006b). Bernard Williams (2006) seeks to explain human attitudes of this kind. He maintains that it is to be expected that humans will stress the interests of humans over nonhuman animals because humans are more important to us. Thus we have an obligation to human need because we are humans. However, as Dale Jamieson notes, though Williams seems to explain human attitudes '...explaining our attitudes is not 
the same as justifying them' (2008: 106). In consequence, Jamieson argues that ' $[\mathrm{t}]$ here is still a question about whether an appeal to our common humanity is sufficient for dividing the moral world along the lines of species membership' (2008: 106). The obligation to the human position that Williams asserts relies on speciesist assumptions that conform with, to use Peter Singer's words, the 'conventional assumption that we are, simply because we are human, justified in overriding the interests of nonhuman animals when they conflict with our own' (2002: 3). Accordingly, the obligation to the human position reiterates human primacy (Peggs, in press), and it is the notion that there is something essential to being human that is fundamentally different to the vast array of nonhuman animals classified as 'animals' that enables the obligation to the human, at the expense of the nonhuman, to be maintained. So, coming back to Williams, Jamieson argues that our speciesism explains 'our moral blindness with respect to the treatment of animals' but he argues, 'once the prejudice of speciesism is overcome, we see that what we do to nonhuman animals is justified only if we are willing to do the same thing in the same circumstances to human beings as well' (Jamieson 2008: 116).

5.8 The assumed essential primacy of human over nonhuman animals becomes increasingly evident upon further examination of Pro-Test's statement 'Animal welfare must be taken into consideration, but ultimately, human beings must come first' (2006b). For Pro-Test there is no doubt that humans 'must come first', but it is important to point out that some accord is given to the interests of nonhuman animals. In her discussion of Baruch Spinoza's and Rene Descartes' exclusion of nonhuman animals from moral concern, Midgley notes that ' $[\mathrm{t}] \mathrm{he}$ most drastic and convinced excluders are those least interested in arguing their position. They find it obvious' (1983: 45). Unlike Spinoza and Descartes the statement 'Animal welfare must be taken into consideration' reveals that Pro-Test does not exclude nonhuman animals from moral concern. However, what Pro-Test finds obvious and what the group takes for granted is that a moral concern for humans is most important since 'human beings must come first'. The group does not seek to justify this statement; rather it seeks to justify nonhuman animal experiments. Consequently the implied conclusiveness of the primacy of human need not only emphasises that this should be so but that it is so, putting these values beyond the bounds of political disagreement. This ensures that doubts about the essential extra importance of humans are, to use Butler's words (which she uses in another context) 'summarily silenced' (quoted in Lloyd 2005: 30).

5.9 The basis of Pro-Test's assumption of the human right to experiment on nonhuman animals is the difference between nonhuman animals and us and their human-defined lesser importance in relation to us. The statement 'Animal welfare must be taken into consideration, but ultimately, human beings must come first' (Pro-Test 2006b) is clear in this regard. In this context the word 'animal' is used to describe creatures other than us, and this conforms with what Midgley calls the 'commonest' use of the word, when the word is used to contrast all others species with our own (2004: 135). Here 'animal' is constructed as the negative of human (at Derrida's subordinate pole), but this use of the description 'animal' for that vast array of creatures who are not human is, according to Midgley, rather puzzling because, as she notes, 'in virtually every respect gorillas are much more like ourselves than they are like (say) skin parasites, or even worms and molluscs' (2004: 135). Indeed, in this regard, Pro-Test stresses that the similarity between human and nonhuman animals is advantageous at least in the case of drug testing because,
'As the genomic revolution has come around and the genomes of both humans and animals have been sequenced, we have realized that there are much more similarities between humans and animals than there are differences. It has also enabled us to identify where humans and particular animals are identical, as some animals serve as accurate representatives of a human's anatomy, while others may share identical biochemical pathways. ' (Pro-Test 2006b) $)^{[5]}$

5.10 So humans and nonhuman animals are different in terms of moral value but are similar enough to make them useful for human scientific needs (see Adams 1995); with the assumed essential biological similarity making the choice to experiment upon nonhuman animals functional and the assumed moral difference making the choice to experiment upon them acceptable.

5.11 The primacy assumption inbuilt into the contention that 'Animal welfare must be taken into consideration, but ultimately, human beings must come first' (Pro-Test 2006b) is exposed when the word 'animal' is replaced with 'female' and the word 'human' is replaced with 'male' in the following way; 'Female welfare must be taken into consideration, but ultimately, male beings must come first'. Apart from the alarming female subordination assumed here and the unquestioning acceptance of the pre-eminence of male needs that follow from this, what we might now notice is that males are considered to be 'beings', unlike females. What might we make of this? Since 'being' is applied to males and not to females it seems unlikely that the word is used in the dictionary sense of 'any person or living thing that may exist or exists' (Chambers 1993). Rather, it is conceivable that 'being' is used here in its restricted sense, to 'denote a subject of consciousness (or self), and thus a kind of entity to be contrasted with mere 'objects' (Honderich 
1995: 82), or perhaps 'being' is here used as a substitute for 'person' (as it would be in the original term 'human being'), which ranks this 'being' higher up the moral scale than beings not seen as 'persons' (Singer 2002: 133). If this 'being' is a person in a moral sense then this being is ascribed rights or duties because 'of the import we attach to the presence of personhood with respect of the wrongness of inflicting specific harms' (Singer 2002: 133). If we return to Pro-Test's original statement it now seems clear that human primacy identity is emphasized since 'human beings must come first' and as a result nonhuman animals used in experiments must come second to those higher up the moral scale. In consequence, the political grouping Pro-Test is seeking to maintain human primacy via primacy identity politics that is based in unquestioned assumptions about essential human identity as separate from and superior to 'animal', and it is via this primacy form of identity that discrimination against the subordinate 'other' is achieved and maintained. Thus, for me, a focus on performative identities makes possible a critique of assumptions of essential primacy identities, whether associated with assumptions of human primacy, male primacy or, coming back to Homfray's paper, heterosexual primacy, and this can surely be used to strengthen emancipatory political goals

\section{Conclusion}

6.1 In his paper Mike Homfray makes a case against the social constructionist critique of essential identity for the goal of emancipation in identity politics. He argues that the concept of identity as associated with the pre-deconstructed subject is central to the emancipatory goal of oppressed groups since essential identity is the basis for collective action that leads to the emancipation of oppressed groups. In this paper I have offered a distinction between radical identity politics that seeks to liberate oppressed groups and primacy identity politics, in which primacy identity is used to maintain the subjugation of oppressed groups. In so doing I have sought to challenge Homfray's somewhat wholesale rejection of the capacity for a social constructionist critique of identity to work for emancipatory politics by focussing on the challenge that the social constructionist critique of essential identity makes to primacy identity politics. Thus I have turned my attention away from the identities of those who are oppressed to the identities of the oppressors because, I argue, this transfer of attention shows how effective the deconstruction of identity could be for the political purpose of the emancipation of oppressed groups. So, for me, the deconstruction of notions of a supreme essential identity and assumed natural primacy is functional for the politics of those who are oppressed. In consequence I argue that primacy identity politics can effectively be challenged by a social constructionist critique of essential identities and thus, contra Homfray, a focus on the deconstruction of essential identity can strengthen emancipatory causes.

6.2 In focusing on the dualism human/'animal' and the human oppression of nonhuman animals in nonhuman animal experiments, I have argued that discourses used by the lobby group Pro-Test reveal how notions of essential human primacy, located in human identity as different from and superior to the nonhuman animal 'other', are taken for granted. Pro-Test has forged the assumption of human primacy into a primacy identity politics via its political campaign to preserve human experiments on nonhuman animals. Thus, to paraphrase Lloyd (2005: 20), the primacy identity 'human' has become for Pro-Test political (has become human primacy identity politics) because an antagonism has emerged with 'anti-vivisectionists' about the use of nonhuman animals in experiments. Such experiments could only take place in an anthropocentric social formation which upholds the speciesist assumption that the interests of humans overrule those of nonhuman animals. Midgley reminds us that '...speciesism has been coined to describe discrimination against non-humans, thereby branding it is an offence against equality, parallel to racism, sexism, ageism and the like' (1983: 65). It is this speciesist discrimination, grounded in essential human identity, which permits the continued oppression of nonhuman animals. What the extract by Midgley also makes clear is that there is correspondence between a range of oppressions. Notions of essential primacy identity are not confined to the 'human'/ 'animal' dualism, they are also applied to dualisms among humans which form the basis of, for example, the oppression of lesbians and gay men (e.g. 'heterosexual'/ 'homosexual'). Thus, contra Homfray (2008), I conclude that the continued assumption of essential identities buttresses the oppression of what Derrida refers to as the second 'marked' groups, whereas the deconstruction of essential identities and the dissolution of power associated with primacy identities (associated with the first 'unmarked' groups) could assist in the emancipation of those who are oppressed.

\section{Notes}

${ }^{1}$ Though present day sociologists have embraced the conceptualisation of fragmented identity, it is not new. As Jack Barbalet (2001: 119) reports, Georg Simmel ([1903] 1971), Ferdinand Tönnies ([1887] 1963) and Louis Wirth [1938] 1957) reflected upon the fragmentary nature of the self.

${ }^{2}$ Mike Homfray (2008) shows that some lesbians and gay men regard their sexual identity as a primary identity. 
${ }^{3}$ Pro-Test supports experiments on nonhuman animals for 'pure research' (that is exploratory research), for 'applied research' (that is directly applicable research like a cures for malaria), and for 'toxicology research' (that is testing substances for lethal effects) (Pro-Test 2006c).

${ }^{4}$ I have cited this extract elsewhere in published work (Peggs, in press)

${ }^{5}$ I have cited this extract elsewhere in published work (Peggs, in press)

\section{References}

ADKINS, L. (2001) Risk Culture, Self-Reflexivity and the making of Sexual Hierarchies' in Body and Society, $7(1): 35-55$

ANDERSON, K. (1998). 'Animals, Science, and Spectacle in the City', in J. Wolch and J. Emel (eds) Animal Geographies: Place, Politics and Identity in the Nature-Culture Borderlands. Pp. 27-50. London and New York: Verso.

BARBALET, J. M. (2001) Emotion, Social Theory and Social Structure: A Macrosociological Approach , Cambridge: Cambridge University Press

BUTLER, J. (1999) Gender Trouble, 2nd edn. London: Routledge.

CHAMBERS (1993). The Chambers Dictionary. Edinburgh: Chambers Harrap.

DERRIDA, J. (2004), 'The Animal That Therefore I am (More to Follow)', in P. Atterton and M. Calarco (eds) Animal Philosophy: Essential Readings in Continental Thought, pp. 113-128. London and New York: Continuum.

DESCARTES, R. (1968) Discourse on Method and Other Writings, Middlesex: Penguin.

FULLER, S. (2006). The New Sociological Imagination . London: Sage.

GIDDENS, A. (1991). Modernity and Self-identity. Cambridge: Polity Press.

GOFFMAN, E. 1969. The Presentation of Self in Everyday Life . Harmondsworth: Penguin.

HALL, S. (1996) 'Introduction: Who Needs Identity?', in S. Hall and P. du Gay (eds) Questions of Cultural Identity, pp1-19. London: Sage.

HOLMES, M. (2007) What is Gender? Sociological Approaches. London: Sage.

HOMFRAY, M. (2008) Standpoint, Objectivity, and Social Construction: Reflections from the Study of Gay and Lesbian Communities. Sociological Research Online 13: 1

$<$ http://www. socresonline.org.uk/13/1/7.html>

HONDERICH () iThe Oxford Companion to Philosophyt. Oxford:

ITO, M. (2008) Seeing Animals, Speaking of Nature: Visual Culture and the Question of the Animal. Theory, Culture and Society, 25 (4) 119- 139.

JAMIESON, D. (2008) Ethics and the Environment: An Introduction, Cambridge: Cambridge University Press

JENKINS, R. (2004) Social Identity, $2^{\text {nd }}$ edn. London and New York: Routledge.

LACLAU, E. (1990) New Reflections on the Revolution of Our Time , London: Verso.

LAMPARD, R. and Peggs, K. (2007) Identity and Repartnering after Separation. Palgrave Macmillan: Basingstoke, Hampshire and New York.

LLOYD, M. (2005) beyond identity politics: feminism, power and politics . London: Sage.

LLOYD, M. (2007) Judith Butler: From Norms to Politics, Cambridge: Polity

MIDGLEY, M. (1983) Animals and Why They Matter, Athens, Georgia: The University of Georgia Press 
MIDGLEY, M. (2002 [1979]). Beast and Man, London: Routledge.

NATIONAL STATISTICS 2007 Statistics on Scientific Procedures on Living Animals in Great Britain 2006. London: The Stationary Office.

OSBORNE, P. and Segal, L. (1994). 'Gender as Performance: an interview with Judith Butler', Radical Philosophy 67:32-9.

PEGGS, K (In press) A hostile world for nonhuman animals: human identification and the oppression of nonhuman animals for human good. Sociology.

PRO-TEST. (2006a). 'About us', Pro-Test: standing up for science, URL (consulted Aug. 2007): $<$ http://www.Pro-Test.org.uk/about.php>.

PRO-TEST. (2006b). 'Frequently Asked Questions', Pro-Test: standing up for science, URL (consulted Aug. 2007): <http://www.Pro-Test.org.uk/facts.php?lt=b>. pp1-4

PRO-TEST. (2006c). 'About The Research', Pro-Test: standing up for science, URL (consulted Aug. 2007): $<$ http://www. pro-test.org.uk/facts. php?lt=d>

PRO-TEST. (2006d). 'Benefits', Pro-Test: standing up for science, URL (consulted Aug. 2007): $<$ http://www.Pro-Test.org.uk/facts.php?lt=b>. pp1-2.

PRO-TEST. (2007). 'Latest News: Pro-Test welcomes Home office statistics on animal research for 2006', Pro-Test: standing up for science, URL (consulted July 2007): <http://www.Pro-Test.org.uk>.

ROWLANDS, M. (2002). Animals Like Us. London: Verso.

SINGER, P. (2002) Unsanctifying Human Life. Ed H. Kuhse. Oxford and Malden MA: Blackwell

SUTCLIFFE, F. E. (1968). 'Introduction', In R. Descartes. Discourse on Method and Other Writings, pp 723. Middlesex: Penguin.

WILLIAMS, B. (2006) Philosophy as a Humanistic Discipline. Princetown: Princetown University Press. 